\title{
Emergence of Cryptococcus spp. in Donkeys in Egypt: A Potential Public Health Concern
}

\author{
Rahma Mohamed, Sara Nader, Dalia Hamza and Maha A. Sabry* \\ Department of Zoonoses, Faculty of Veterinary Medicine, Cairo University, Giza \\ Square, PO Box 12211, Cairo, Egypt
}

\begin{abstract}
A B S T R A C T
Cryptococcus has gained medical importance over the last decade, as it is an emerging pathogen among immunocompetent individuals. There are no epidemiological data on the prevalence of this fungus in donkeys. The current research was conducted to investigate the possible role of the Egyptian donkeys in the epidemiology of such pathogen. Bacteriological analysis of nasal swabs of 52 diseased and healthy donkeys at different localities in Egypt revealed that the overall occurrence of Cryptococcus spp. was $11.5 \%$. The highest proportion was in El-Fayoum Governorate (25). Phenotypic identification of Cryptococcus indicated that $13.2 \%$ and $7.1 \%$ among healthy and diseased donkeys were positive for this pathogen, respectively. The study of the potential risk factors associated with Cryptococcus colonization in the donkeys did not show any statistically significant differences. Molecular serotyping of 6 identified Cryptococcus spp. evidenced $C$. gattii in the nasal passages of 4 healthy donkeys (7.7\%); while the other 2 C. neoformans serotype A (3.8\%) isolates identified in healthy and diseased donkeys. Four C. gattii and C. neoformans isolates demonstrated higher laccase ( $L A C 1)$ genes among the identified virulence factors. While capsular associated protein (CAP59) gene identified alone or associated with $L A C 1$ gene in the other 2 C. gattii isolates. This study underlines a potential association of those fungi with human disease in Egypt. In order to strengthen existing therapeutic and control approaches, further analyses of the main risk factors and the other virulence of these pathogens should be further considered.
\end{abstract}

Article Information

Received 10 December 2020

Revised 11 January 2021

Accepted 20 January 2021

Available online 30 July 2021

Authors' Contribution

$\mathrm{RM}$ and $\mathrm{SN}$ collected and prepared

the samples, applied bacteriological

analysis and PCR assay. DH helped

in laboratory work, reviewing

and editing. MAS supervised the

study, data curation and wrote the manuscript.

Key words

Donkeys, Cryptococcus neoformans,

Cryptococcus gattii, Nasal swabs,

Potential risk factors, Virulence

factors, Laccase gene, Capsular associated protein gene.

\section{INTRODUCTION}

$\mathrm{R}$ ecently fungal pathogens, Cryptococcus spp. have increasingly been recognized as a major threat to the populations' health worldwide. There are at least 37 distinct Cryptococcus spp. of which Cryptococcus neoformans and Cryptococcus gattii are human pathogens (Kwon-Chung et al., 2017). C. neoformans taxonomic classification illustrated $C$. neoformans and $C$. deneoformans as $C$. neoformans serotype A has three genotypes: VNI, VNII, and VNB and $C$. deneoformans serotype D has a genotype VNIV. In the case of $C$. gattii, there are five cryptic species with serotypes B, C and genotype from VGI to IV (Hagen et al., 2015). While all of the serotypes can vary in their topographical distribution, they can all cause disease in humans and animals. Annually, approximately 625,000 deaths are reported for one million cases of cryptococcal meningitis among people with HIV/AIDS due to infection with those species (Centers for Disease Control and Prevention, CDC, Atlanta, USA, http://www.cdc.gov/). $C$. gattii appears to have a greater propensity to infect immunecompetent humans (Rozenbaum and Gonçalves, 1994; Speed and Dunt, 1995). The infection is transmitted from

\footnotetext{
Corresponding author: profdrmahaas@yahoo.com 0030-9923/2021/0005-1873 \$ 9.00/0

Copyright 2021 Zoological Society of Pakistan
}

environment by inhalation of spores or dehydrated yeast cells that can enter the pulmonary alveoli and then spread through the bloodstream causing respiratory disorders such as pneumonia, soft tissue disease, and most frequently meningoencephalitis (Kwon-Chung et al., 2014).

As a result of the environmental changes, the number of fungal diseases in animals and plants has increased (Fisher et al., 2012). C. neoformans have not only been isolated from avian excreta but also from soil and house dust (Swinne et al., 1986; Irokanulo et al., 1997; Litvintseva et al., 2011) as well as exotic, migratory birds, domestic and wild animals may be carriers or susceptible hosts for this species (Casadevall and Perfect, 1998). Additionally, $C$. gattii species complex can colonize the plethora of tree species (Vélez and Escandón, 2017).

In Egypt, Saleh (2005) isolated C. neoformans from vaginal swabs examined from different animal species. The same pathogen (C. neoformans) was also isolated from throat and vaginal swabs from women rearing pigeons (Saleh et al., 2011). Environmental surveys conducted in eight African countries including Egypt showed that these pathogens represented $1 \%$ of the total recorded environmental isolates (Cogliati, 2013).

The last statistics from Food and Agriculture Organization (FAO) estimates that about 3.3 million donkeys (Equus asinus) live in Egypt. A vast majority of these donkeys are daily working animals and they form the 
country's second largest population of livestock after goats in the region. Similar to other mammals, as reported by Fisher et al. (2012), donkeys and horses may be affected by several fungal diseases which pose a serious threat to them. In horses, cryptococcosis is primarily associated with respiratory tract disorders, central nervous system (CNS), and premature birth. Disseminated cryptococcosis is documented in horses (Zoppa et al., 2008), whereas cutaneous cryptococcosis in donkeys was reported (Khodakaram-Tafti and Dehghani, 2006).

The health of these working animals is closely linked to the health of the human population, from the one health principle. Therefore, there is an urgent need to investigate the role of donkeys in Egypt's cryptococcal epidemiological process. Since no epidemiological data are available in Egypt among cryptococcal infection in donkeys, the current research was conducted to investigate the occurrence of Cryptococcus species among healthy and diseased donkeys and to determine their serotypes and virulence factors.

\section{MATERIALS AND METHODS}

\section{Samples collection and preparation}

Nasal swabs were collected from donkeys raised in different localities in Cairo, Giza, and El-Fayoum Governorates. Donkeys included were 38 apparently healthy and 14 diseased suffering from wounds, mobility disorder, stomatitis, nasal discharge, ocular discharge or abscess. The swab samples were inoculated into sterile Sabouraud dextrose broth (Oxoid) supplemented with chloramphenicol $(0.1 \mathrm{~g} / \mathrm{L})$ (HiMedia), then were transported to the laboratory in ice box. Data from each individual animal were collected including age, sex and underlying health issues.

Protocol of samples collection was carried out in compliance with the recommendations of the Institutional
Animal Care and Use Committee (IACUC) of the Faculty of Veterinary Medicine, Cairo University, Egypt (VetCU20022020123).

Isolation and phenotypic identification of Cryptococcus spp.

According to Horta et al. (2002), the inoculated swab samples were incubated at $37^{\circ} \mathrm{C}$ for $24 \mathrm{~h}$. Then the prepared sample supernatant was streaked onto plates of SDA with chloramphenicol, and was incubated for 48-72 $\mathrm{h}$ at $37^{\circ} \mathrm{C}$. The colonies with a mucoid like appearance (Supplementary Fig. S1) were selected and were identified by microscopic morphology of yeast cells.

For identification of Cryptococcus isolates based on melanin synthesis, a loop from the original broth were streaked onto Tobacoo agar media (TAM) plates and incubated for 3-5 days at $37^{\circ} \mathrm{C}$ (Tendolkar et al., 2003; Refai et al., 2005). Biochemical identification of the colonies was done using RapID yeast plus system (RYP) (Remel, USA) (Smith et al., 1999; Soltani et al., 2013).

\section{Molecular identification}

Genomic DNA were extracted from the pure Cryptococcus isolates using boiling method according to Mohammadi et al. (2017).

Multiplex PCR was carried out using specific oligonucleotide primers (Table I) to detect $C$. neoformans serotype A and $C$. gattii serotype $\mathrm{B}$. The PCR reactions were performed in a total volume of $25 \mu \mathrm{l}$, containing $3 \mu \mathrm{l}$ of template DNA from each isolate, $12.5 \mu 1$ of Master Mix (takara, Japan), $0.5 \mu 1$ of each primer (Metabion, Germany) and $7.5 \mu 1$ of PCR grade water.The PCR reaction mixtures were amplified using thermal profile conditions (Table II). The PCR amplicons were electrophoresed on agarose gel $(1.5 \%)$ at $100 \mathrm{~V}$ for $60 \mathrm{~min}$ and visualized under ultraviolet light.

Table I.- Sequence of oligonucleotide primers for molecular serotyping of $C$. neoformans and $C$. gattii and identification of the virulence genes in the isolates.

\begin{tabular}{|c|c|c|c|}
\hline Target genes & Primer sequence (5'-3') & Amplicon size (bp) & References \\
\hline C. neoformans, $\mathrm{CNa}-70 \mathrm{~S}$ & ATTGCGTCCACCAAGGAGCTC & \multirow[t]{2}{*}{695} & Aoki et al. (1999); \\
\hline$C N a-70 A$ & ATTGCGTCCATGTTACG TGGC & & Lusia-Leal et al. (2008) \\
\hline C. gattii, $C N b-49 S$ & ATTGCGTCCAAGGTGTTGTTG & \multirow[t]{2}{*}{448} & \\
\hline$C N b-49 A$ & ATTGCGTCCATCCA ACCGTTATC & & \\
\hline \multirow[t]{2}{*}{ Laccase gene, $L A C 1$} & AACATGTTCCCTGGGCCTGTG & \multirow[t]{2}{*}{469} & Fraser et al. (2005); \\
\hline & ATGAGAATTGAATCGCCTTGT & & Meyer et al. (2009) \\
\hline \multirow{2}{*}{$\begin{array}{l}\text { Capsular associated protein, } \\
\text { CAP59 }\end{array}$} & CTCTACGTCGAGCAAGTCAAG & \multirow[t]{2}{*}{559} & \\
\hline & CCGCTGCACAAGTGATACCC & & \\
\hline \multirow[t]{2}{*}{ Phospholipase, $P L B 1$} & CTTCAGGCGGAGAGAGGTTT & \multirow[t]{2}{*}{532} & Litvintseva et al. (2006); \\
\hline & GATTTGGCGTTGGTTTCAGT & & Meyer et al. (2009) \\
\hline
\end{tabular}


Table II.- PCR amplification thermal conditions of $C$. neoformans and $C$. gattii serotypes and virulence genes of the isolates.

\begin{tabular}{|c|c|c|c|c|c|c|}
\hline Gene & $\begin{array}{c}\text { Initial } \\
\text { denaturation }\end{array}$ & $\begin{array}{c}\text { Secondary } \\
\text { denaturation }\end{array}$ & Annealing & Extension & $\begin{array}{l}\text { No. of } \\
\text { cycles }\end{array}$ & $\begin{array}{c}\text { Final } \\
\text { extension }\end{array}$ \\
\hline $\mathrm{CNa}-70 \mathrm{~S}$ & $94^{\circ} \mathrm{C}$ & $94^{\circ} \mathrm{C}$ & $65^{\circ} \mathrm{C}$ & $72^{\circ} \mathrm{C}$ & 35 & $72^{\circ} \mathrm{C}$ \\
\hline$C N a-70 A$ & $8 \mathrm{~min}$ & $1 \mathrm{~min}$ & $1 \mathrm{~min}$ & $2 \mathrm{~min}$ & & $8 \mathrm{~min}$. \\
\hline \multicolumn{7}{|l|}{$\begin{array}{l}C N b-49 S \\
C N b-49 A\end{array}$} \\
\hline$L A C 1$ & $\begin{array}{l}94^{\circ} \mathrm{C} \\
3 \mathrm{~min} .\end{array}$ & $\begin{array}{l}94^{\circ} \mathrm{C} \\
30 \mathrm{sec} .\end{array}$ & $\begin{array}{c}58^{\circ} \mathrm{C} \\
30 \mathrm{sec} .\end{array}$ & $\begin{array}{l}72^{\circ} \mathrm{C} \\
1 \mathrm{~min}\end{array}$ & 30 & $\begin{array}{l}72^{\circ} \mathrm{C} \\
5 \mathrm{~min}\end{array}$ \\
\hline CAP59 & $\begin{array}{l}94^{\circ} \mathrm{C} \\
3 \mathrm{~min}\end{array}$ & $\begin{array}{c}94^{\circ} \mathrm{C} \\
30 \mathrm{sec}\end{array}$ & $\begin{array}{l}56^{\circ} \mathrm{C} \\
30 \mathrm{sec} .\end{array}$ & $\begin{array}{l}72^{\circ} \mathrm{C} \\
1 \mathrm{~min}\end{array}$ & 35 & $\begin{array}{l}72^{\circ} \mathrm{C} \\
5 \mathrm{~min} .\end{array}$ \\
\hline PLB1 & $\begin{array}{l}94^{\circ} \mathrm{C} \\
3 \mathrm{~min} .\end{array}$ & $\begin{array}{c}94^{\circ} \mathrm{C} \\
45 \mathrm{sec} .\end{array}$ & $\begin{array}{c}61^{\circ} \mathrm{C} \\
45 \mathrm{sec} .\end{array}$ & $\begin{array}{l}72^{\circ} \mathrm{C} \\
1 \mathrm{~min}\end{array}$ & 30 & $\begin{array}{l}72^{\circ} \mathrm{C} \\
5 \mathrm{~min}\end{array}$ \\
\hline
\end{tabular}

Molecular detection of the virulence genes

The extracted DNA from Cryptococcus spp. isolates were also examined for the presence of the virulence genes; laccase gene $(L A C 1)$, capsular associated protein (CAP59), and Phospholipase PLB1.

Uniplex PCR was performed using specific oligonucleotides primers shown in Table I. The PCR reaction mixtures of $25 \mu \mathrm{l}$ total volume contain $12.5 \mu \mathrm{l}$ of Master Mix (takara, Japan), $0.5 \mu 1$ of each primer (Metabion, Germany), $8.5 \mu \mathrm{l}$ water and $3 \mu \mathrm{l}$ template DNA from each isolate. Negative control was included which contains all the components of the PCR mixture, but with water instead of the template DNA. The PCR reaction mixtures were amplified using thermal profile conditions (Table II).

\section{Statistical analysis}

Data were collected, tabulated and statistically analysed with PASW, version 18.0, Software (SPSS Inc., Chicago, IL, USA). Fisher's Exact test and FisherFreeman-Halton Exact test (Freeman and Halton, 1951) (it is the Fisher's Exact test for contingency tables greater than $2 \times 2$ ) were used. Statistically significant $P$-value is less than 0.05 .

\section{RESULTS}

Table III shows occurrence of Cryptococcus spp. in healthy $(13.2 \%)$ and diseased (7.1\%) donkeys. The highest percentage of occurrence of Cryptococcus spp. was in donkeys $>10$ year of age (14.3), while in both males $(11.4 \%)$ and females $(11.8 \%)$ the pathogen was almost identical (Table IV).

Molecular serotyping of 6 identified Cryptococcus spp. evidenced that $C$. gattii B was isolated from the nasal passages of four donkeys (7.7\%), it was recovered from healthy examined donkeys, while the other $2 \mathrm{C}$. neoformans A isolates (3.8\%) were identified in healthy and diseased donkeys (Table III). Clinical condition was recorded in only one 12 year -old male donkey (16.7\%) with stomatitis among the 6 positive donkeys.

Table III.- Occurrence of Cryptococcus spp. among healthy and diseased donkeys.

\begin{tabular}{llccc}
\hline \multirow{2}{*}{$\begin{array}{l}\text { Underlying health } \\
\text { condition }\end{array}$} & $\begin{array}{l}\text { No. of } \\
\text { samples }\end{array}$ & \multicolumn{3}{c}{ Positive samples } \\
\cline { 3 - 5 } & & C. neoformans & C. gattii & Total \\
\hline Healthy & 38 & 1 & 4 & 5 \\
Diseased & 14 & 1 & 0 & 1 \\
Total & 52 & 2 & 4 & 6 \\
\hline
\end{tabular}

Table IV.- Occurrence of Cryptococcus spp. according to the age and gender of the examined donkeys.

\begin{tabular}{llcc}
\hline $\begin{array}{l}\text { Predisposing } \\
\text { factors }\end{array}$ & $\begin{array}{c}\text { No. of } \\
\text { samples }\end{array}$ & $\begin{array}{c}\text { No. of positive } \\
\text { samples }\end{array}$ \\
\hline Age & $1-5$ & 33 & 4 \\
(year) & $6-10$ & 12 & 1 \\
& $>10$ & 7 & 1 \\
Total & & 52 & 6 \\
Gender & Male & 35 & 4 \\
& Female & 17 & 2 \\
Total & & 52 & 6 \\
\hline
\end{tabular}

Bacteriological examination of 52 nasal swabs collected from diseased and healthy donkeys at different localities in Egypt, evidenced that the overall occurrence 
of Cryptococcus spp. was $11.5 \%$. The highest percentage was reported in El-Fayoum Governorate (25\%) followed by Cairo Governorate $(10 \%)$. The lowest percentage of Cryptococcus spp. was recorded in Giza Governorate $(8.8 \%)$ as shown in Table V. The statistical analysis showed that there is no significant difference $(P=0.363$, Fisher's exact test) between the examined localities.

Table VI shows that laccase gene was the most frequently detected gene in 4 isolates of $C$. gattii (B) and C. neoformans (A). While capsular associated protein gene was found in the other two isolates of C. gattii (B) alone or associated with $L A C l$. The Phospholipase gene was however not identified in any species.

Table V.- Occurrence of Cryptococcus spp. in donkeys originated from different localities.

\begin{tabular}{lccc}
\hline Location & $\begin{array}{c}\text { No. of } \\
\text { samples }\end{array}$ & $\begin{array}{c}\text { No. of positive } \\
\text { samples }\end{array}$ & $\begin{array}{c}\text { \% of positive } \\
\text { samples }\end{array}$ \\
\hline Cairo & 10 & 1 & 10.0 \\
Giza & 34 & 3 & 8.8 \\
El-Fayoum & 8 & 2 & 25.0 \\
Total & 52 & 6 & 11.5 \\
\hline
\end{tabular}

Table VI.- The virulence factors identified among $C$. neoformans and $C$. gattii isolates.

\begin{tabular}{|c|c|c|c|c|}
\hline \multirow[t]{2}{*}{ Serotypes } & \multicolumn{4}{|c|}{ Virulence pattern } \\
\hline & $L A C 1$ & CAP59 & $\begin{array}{c}\text { LAC1 \& } \\
\text { CAP59 }\end{array}$ & $P L B 1$ \\
\hline C. gattii (B), $\mathrm{n}=4$ & 2 & 1 & 1 & 0 \\
\hline C. neoformans (A), $\mathrm{n}=2$ & 2 & 0 & 0 & 0 \\
\hline
\end{tabular}

\section{DISCUSSION}

The number of fungal and fungal-like diseases of plants and animals in both natural and controlled systems has increased over the last two decades, most likely as a result of the environmental changes (Fisher et al., 2012). As well as, the number of debilitated individuals is progressively increasing.

A significant number of literature focuses on individual clinical cases, whereas less is known about the disease epidemiology in horses (Duncan et al., 2011). To our knowledge, the role of donkeys has not been specifically investigated in this pathogen's epidemiology. In order to study the epidemiology of cryptococcosis, a diagnostic method is required to detect the presence of Cryptococcus spp. in serum, tissue samples, and nasalswab samples (Krockenberger et al., 2003; Raso et al., 2004; Duncan et al., 2005, 2006a, b). In the current study, the overall recorded percentage of Cryptococcus spp. $(11.5 \%)$ detected in nasal passages of the examined donkeys was nearly similar to those estimated by Danesi et al. (2014) who examined 766 cats nasal swabs and recovered Cryptococcus spp. from 95 (12.6\%).

Our findings showed that apparently healthy donkeys are asymptomatic carriers of Cryptococcus spp. as, the highest occurrence of Cryptococcus spp. was detected in nasal passages of healthy examined donkeys, it indicates that the organism's environmental load in the studied area is significantly greater. In this context, Connolly et al. (1999) and Malik et al. (1997) reported that Cryptococcus environmental exposure and asymptomatic colonization of the respiratory tract much more common than clinical disease.

C. neoformans and C. gattii are commonly regarded as pathogenic species of the genus Cryptococcus. Molecular serotyping of the detected Cryptococcus spp. isolates in the current study revealed that $C$. gattii (B) was frequently detected among apparently healthy examined donkeys in relation to C. neoformans (A). Host factors that restrict the fungus to the respiratory tract without any symptoms may be attributed to incomplete elimination of Cryptococcus cells by alveolar macrophages that involved in host response against infection (Lin and Heitman, 2006).

The C. gattii fungal pathogen can infect hosts with and without an apparent immune defect. Duncan et al. (2005) recorded that asymptomatic carriage of $C$. gattii has been recognized in companion animal species of British Columbia, Canada, with most of the reported individuals remaining asymptomatic.

Lately, C. gattii came to public consciousness due to the outbreak of devastating disease in immunocompetent people. The first case of $C$. neoformans var. gattii serotype (B) from Egypt was detected in an HIV patient (Mansour et al., 2006). This serotype has also been identified as a potential main agent of granulomatous rhinitis in horses (Cruz et al., 2017). Species identification was necessary because $C$. gattii infections are increasingly considered alarming as it becomes more difficult to handle this fungus, because it is not susceptible to the most widely used antifungal agents (Trilles et al., 2004), as well as this pathogen infects the immunocompetent hosts, particularly children.

Age, sex, and health conditions of the individual animals have no statistically significant impact on Cryptococcus spp. nasal colonization as shown in the present study. This could be arguing for the presence of other risk factors such as the environment. Determining such possible factors can help animal-owners and veterinarians mitigate the risk of Cryptococcus spp. 
infection.

The highest recorded occurrence of Cryptococcus spp. isolates in donkeys from El-Fayoum Governorate may reflect the environmental presence of Cryptococci which is presumably greater around the examined donkeys and this may be due to the presence of pigeons in the examined area. Chowdhary et al. (2012) and Datta et al. (2009) have confirmed this; they declared that Cryptococcus species are associated with environmental niches rich in avian guanos, particularly pigeon excreta (C. neoformans) and decaying vegetation.

Pathogenicity of a microbe relies on the existence of virulence factors that function to induce illness in unison. Since these factors are involved not only in pathogenesis but also in commensalism, some of the virulence genes have been molecularly identified among the isolates.

It is intriguing that all $C$. neoformans and $C$. gattii isolates in this study shared the same virulence factor, as they have laccase gene, this finding was confirmed by Ellerbroek et al. (2004) who declared C. neoformans and $C$. gattii have several common virulence factors.

The cryptococcal laccase determinant is a wellcharacterized virulence factor, producing a melanin cell wall coat that defends the cell against environmental factors; host attacks and antimycotic therapy less effectively cleanse it.

The absence of CAP59 gene in the most researched isolates in the present study does not indicate that these phenotypes are virulent. As, the CAP59 gene is not the only determinant responsible for the formation of capsules; three other associated capsule genes (CAP10, CAP60, CAP64) have been shown to be important for the development of Cryptococcus capsules (Okabayashi et al., 2007).

In fact, even though most of the identified reported Cryptococcus phenotypes were uncapsulated, the awareness of these forms is an important consideration, particularly in immunocompetent hosts which can display unusual courses and challenge timely diagnosis.

Furthermore, Sorrell (2001) study confirmed that the virulence of the fungus and severity of infection is the sum of the route of infection, the other variables such as the C. gattii serotype, pathogenic infectious dose, and host immune status.

\section{CONCLUSION}

Current results indicate that Cryptococcus species other than $C$. neoformans may colonize nasal vestibule of asymptomatic donkeys. The low prevalence of $C$. neoformans indicated limited environmental existence of these fungi in the areas examined. C. gattii is common in nature, and its existence in the nasal passages of donkeys suggests that there might be suitable niches for the environmental development of this species in the areas studied. Furthermore, this reinforces the hypothesis that changes in Cryptococcus host preferences can be continuous. In order to clarify the epidemiology of this fungus in donkeys and strengthen therapeutic and control approaches, more research to examine the main risk factors of these pathogens should be considered.

\section{Supplementary material}

There is supplementary material associated with this article. Access the material online at: https://dx.doi. org/10.17582/journal.pjz/20201210211243

Statement of conflict of interest

The authors have declared no conflict of interests.

\section{REFERENCES}

Aoki, F.H., Imai, T., Tanaka, R., Mikami, Y., Taguchi, H., Nishimura, N.F., Nishimura, K., Miyaji, M., Schreiber, A.Z. and Branchini, M.L.M., 1999. New PCR primer pairs specific for Cryptococcus neoformans serotype A or B prepared on the basis of random amplified polymorphic DNA fingerprint pattern analyses. J. clin. Microbiol., 37: 315-320. https://doi.org/10.1128/JCM.37.2.315-320.1999

Casadevall, A. and Perfect, J.R., 1998. Cryptococcus neoformans. ASM Press, Washington, DC, pp. 595. https://doi.org/10.1128/9781555818241

Chowdhary, A., Randhawa, H.S., Boekhout, T., Hagen, F., Klaassen, C.H. and Meis, J.F., 2012. Temperate climate niche for Cryptococcus gattii in Northern Europe. Emerg. Infect. Dis., 18: 172. https://doi. org/10.3201/eid1801.111190

Cogliati, M., 2013. Global molecular epidemiology of Cryptococcus neoformans and Cryptococcus gattii: An atlas of the molecular types. Scientifica, 2013: 675213. https://doi.org/10.1155/2013/675213

Connolly, J.H., Krockenberger, M.B., Malik, R., Canfield, P.J., Wigney, D.I. and Muir, D.B., 1999. Asymptomatic carriage of Cryptococcus neoformans in the nasal cavity of the koala (Phascolarctoscinereus). Med. Mycol., 37: 331-338. https://doi.org/10.1046/j.1365-280X.1999.00236.x

Cruz, R.A., Matheus, R., Ronaldo, V., Maiara, A. and Andréia, S., 2017. Equine nasopharyngeal cryptococcoma due to Cryptococcus gattii. Cienc. Rural., 47: 10. https://doi.org/10.1590/01038478cr20170151

Danesi, P., Furnari, C., Granato, A., Schivo, A., Otranto, 
D., Capelli, G.A. and Cafarchia C., 2014. Molecular identity and prevalence of Cryptococcus spp. nasal carriage in asymptomatic feral cats in Italy. Med. Mycol., 52: 667-673. https://doi.org/10.1093/mmy/ myu030

Datta, K., Bartlett, K.H., Baer, R., Byrnes, E., Galanis, E., Heitman, J., Hoang, L., Leslie, M.J., MacDougall, L., Magill, S.S. and Morshed, M.G., 2009. Spread of Cryptococcus gattii into Pacific Northwest region of the United States. Emerg. Infect. Dis., 15: 1185. https://doi.org/10.3201/eid1508.081384

Duncan, C., Bartlett, K.H., Lester, S., Bobsien, B., Campbell, J., Stephen, C. and Raverty, S., 2011. Surveillance for Cryptococcus gattii in horses of Vancouver Island, British Columbia, Canada. Med. Mycol., 49: 734-738. https://doi.org/10.3109/13693 786.2011.560196

Duncan, C., Schwantje, H., Stephen, C., Campbell, J. and Bartlett, K., 2006a. Cryptococcus gattii in wildlife of Vancouver Island, British Columbia, Canada. J. Wildl. Dis., 42: 175-178. https://doi. org/10.7589/0090-3558-42.1.175

Duncan, C., Stephen, C. and Campbell, J., 2006b. Clinical characteristics and predictors of mortality for Cryptococcus gattii infection in dogs and cats of southwestern British Columbia. Can. Vet. J., 47: 993.

Duncan, C., Stephen, C., Lester, S. and Bartlett, K.H., 2005. Sub-clinical infection and asymptomatic carriage of Cryptococcus gattii in dogs and cats during an outbreak of cryptococcosis. Med. Mycol., 43: 511-516. https://doi. org/10.1080/13693780500036019

Ellerbroek, P.M., El-Annemiek, M., Hoepelman, A.I. and Coenjaerts, F.E., 2004. Effects of the capsular polysaccharides of Cryptococcus neoformans on phagocyte migration and inflammatory mediators. Curr. med. Chem., 11: 253-266. https://doi. org/10.2174/0929867043456188

Fisher, M.C., Henk, D.A., Briggs, C.J., Brownstein, J.S., Madoff, L.C., McCraw, S.L. and Gurr, S.J., 2012. Emerging fungal threats to animal, plant and ecosystem health. Nature, 484: 186-194. https:// doi.org/10.1038/nature10947

Fraser, J.A., Giles, S.S., Wenink, E.C., Geunes-Boyer, S.G., Wright, J.R., Diezmann, S., Allen, A., Stajich, J.E., Dietrich, F.S., Perfect, J.R. and Heitman, J., 2005. Same-sex mating and the origin of the Vancouver Island Cryptococcus gattii outbreak. Nature, 437: 1360-1364. https://doi.org/10.1038/ nature 04220

Freeman, G.H. and Halton, J.H., 1951. Note on an exact treatment of contingency, goodness of fit and other problems of significance. Biometrika, 38: 141-149. https://doi.org/10.1093/biomet/38.1-2.141

Hagen, F., Khayhan, K., Theelen, B., Kolecka, A., Polacheck, I., Sionov, E., Falk, R., Parnmen, S., Lumbsch, H.T. and Boekhout, T., 2015. Recognition of seven species in the Cryptococcus gattii / Cryptococcus neoformans species complex. Fungal Genet. Biol., 78: 16-48. https://doi. org/10.1016/j.fgb.2015.02.009

Horta, J.A., Staats, C.C., Casali, A.K., Ribeiro, A.M., Schrank, I.S., Schrank, A. and Vainstein, M.H., 2002. Epidemiological aspects of clinical and environmental Cryptococcus neoformans isolates in the Brazilian state Rio Grande do Sul. Med. Mycol., 40: 565-571. https://doi.org/10.1080/714031150

Irokanulo, E.O.A., Makinde, A.A., Akuesgi, C.O. and Ekwonu, M., 1997. Cryptococcus neoformans var neoformans isolated from droppings of captive birds in Nigeria. J. Wildl. Dis., 33: 343-345. https:// doi.org/10.7589/0090-3558-33.2.343

Khodakaram-Tafti, A. and Dehghani, S., 2006. Cutaneous cryptococcosis in a donkey. Comp. clin. Pathol., 15: 271-273. https://doi.org/10.1007/ s00580-006-0641-3

Krockenberger, M.B., Canfield, P.J. and Malik, R., 2003. Cryptococcus neoformans var. gattii in the koala (Phascolarctoscinereus): A review of 43 cases of cryptococcosis. Med. Mycol., 41: 225-234. https:// doi.org/10.1080/369378031000137242

Kwon-Chung, K.J., Bennett, J.E., Wickes, B.L., Meyer, W., Cuomo, C.A., Wollenburg, K.R., Bicanic, T.A., Castañeda, E., Chang, Y.C., Chen, J. and Cogliati, M., 2017. The case for adopting the "species complex" nomenclature for the etiologic agents of cryptococcosis. MSphere, 2: e00357-16. https://doi. org/10.1128/mSphere.00357-16

Kwon-Chung, K.J., Fraser, J.A., Doering, T.L., Wang, Z.A., Janbon, G., Idnurm, A. and Bahn, Y.S., 2014. Cryptococcus neoformans and Cryptococcus gattii, the etiologic agents of cryptococcosis. Perspect. Med., 4: a019760. https://doi.org/10.1101/ cshperspect.a019760

Lin, X. and Heitman, J., 2006. The biology of the Cryptococcus neoformans species complex. Annu. Rev. Microbiol., 60: 69-105. https://doi. org/10.1146/annurev.micro.60.080805.142102

Litvintseva, A.P., Carbone, I., Rossouw, J., Thakur, R., Govender, N.P. and Mitchell, T.G., 2011. Evidence that the human pathogenic fungus Cryptococcus neoformans var. grubii may have evolved in Africa. PLoS One, 6: e19688. https://doi.org/10.1371/ 
journal.pone.0019688

Litvintseva, A.P., Thakur, R., Vilgalys, R. and Mitchell, T.G., 2006. Multilocus sequence typing reveals three genetic subpopulations of Cryptococcus neoformans var. grubii (serotype A), including a unique population in Botswana. Genetics, 172: 2223-2238. https://doi.org/10.1534/ genetics.105.046672

Lusia-Leal, A., Faganello, J., Cristina Bassanesi, M. and Vainstein, M.H., 2008. Cryptococcus species identification by multiplex PCR. Med. Mycol., 46: 377-383. https://doi. org/10.1080/13693780701824429

Malik, R., Wigney, D.I., Muir, D.B. and Love, D.N., 1997. Asymptomatic carriage of Cryptococcus neoformans in the nasal cavity of dogs and cats. J. med. Vet. Mycol., 35: 27-31. https://doi. org/10.1080/02681219780000831

Mansour, A., Nakhla, I., El-Sherif, M., Sultan, Y.A. and Frenck, R.W., 2006. Cryptococcus neoformans var. gattii meningitis in Egypt: A case report. $E$ Mediterr. Hlth. J., 12: 241-244.

Meyer, W., Aanensen, D.M., Boekhout, T., Cogliati, M., Diaz, M.R., Esposto, M.C., Fisher, M., Gilgado, F., Hagen, F., Kaocharoen, S. and Litvintseva, A.P., 2009. Consensus multi-locus sequence typing scheme for Cryptococcus neoformans and Cryptococcus gattii. Med. Mycol., 47: 561-570. https://doi.org/10.1080/13693780902953886

Mohammadi, A., Hashemi, S.M., Abtahi, S.H., Lajevardi, S.M., Kianipour, S. and Mohammadi, R., 2017. An investigation on non-invasive fungal sinusitis; molecular identification of etiologic agents. J. Res. med. Sci., 22: 67. https://doi. org/10.4103/jrms.JRMS_166_17

Okabayashi, K., Hasegawa, A. and Watanabe, T., 2007. Microreview: Capsule-associated genes of Cryptococcus neoformans. Mycopathologia, 163: 1. https://doi.org/10.1007/s11046-006-0083-0

Raso, T.F., Werther, K., Miranda, E.T. and MendesGiannini, M.J.S., 2004. Cryptococcosis outbreak in psittacine birds in Brazil. Med. Mycol., 42: $355-$ 362. https://doi.org/10.1080/136937804100017120 61

Refai, M., Kotb, M.R., El-Yazeed, H.A., Tawakkol, W., El-Aarosi, R. and El-Hariri, M., 2005. Development of brown colonies and capsule of Cryptococcus neoformans on plant extract agar and media containing oils Mycology. In: Proceedings of the Annual Meeting of the German-Speaking Mycological Society, 3: 25-27.

Rozenbaum, R. and Gonçalves, A.J.R., 1994.
Clinical epidemiological study of 171 cases of cryptococcosis. Clin. Infect. Dis., 18: 369-380. https://doi.org/10.1093/clinids/18.3.369

Saleh, H.A.E, 2005. Mycological studies on C. neoformans and other yeasts isolated from clinical cases and environment. M.V.Sc. thesis, Department of Microbiology, Faculty of Veterinary Medicine, Cairo University.

Saleh, H., Moawad, A.A., El-Hariri, M. and Refai, M.K., 2011. Prevalence of yeasts in human, animals and soil sample in El-Fayoum Governorate in Egypt. Int. J. Microbiol., 2: 233-239.

Smith, M.B., Dunklee, D., Vu, H. and Woods, G.L., 1999. Comparative performance of the RapID yeast plus system and the API 20C AUX clinical yeast system. J. clin. Microbiol., 37: 2697-2698. https://doi.org/10.1128/JCM.37.8.2697-2698.1999

Soltani, M., Bayat, M., Hashemi, S.J., Zia, M. and Pestechian, N., 2013. Isolation of Cryptococcus neoformans and other opportunistic fungi from pigeon droppings. J. Res. Med. Sci., 18: 56.

Sorrell, T.C., 2001. Cryptococcus neoformans variety gattii. Med. Mycol., 39: 155-168. https://doi. org/10.1080/714031012

Speed, B. and Dunt, D., 1995. Clinical and host differences between infections with the two varieties of Cryptococcus neoformans. Clin. Infect. Dis., 21: 28-34. https://doi.org/10.1093/clinids/21.1.28

Swinne, D., Kayembe, K. and Niyimi, M., 1986. Isolation of saprophytic Cryptococcus neoformans var. neoformans in Kinshasa, Zaire. Annls. Soc. Belg. Med. Trop., 66: 57-61.

Tendolkar, U., Tainwala, S., Jog, S. and Mathur, M., 2003. Use of a new medium-tobacco agar, for pigment production of Cryptococcus neoformans. Indian J. med. Microbiol., 21: 277.

Trilles, L., Fernández-Torres, B., dos Santos Lazéra, M., Wanke, B. and Guarro, J., 2004. In vitro antifungal susceptibility of Cryptococcus gattii. J. clin. Microbiol., 42: 4815-4817. https://doi.org/10.1128/ JCM.42.10.4815-4817.2004

Vélez, N. and Escandón, P., 2017. Report on novel environmental niches for Cryptococcus neoformans and Cryptococcus gattii in Colombia: Tabebuiaguayacan and Roystonearegia. Med. Mycol., 55: 794-797.

Zoppa, A.L.V., Crispim, R., Sinhorini, I.L., Benites, N.R., Silva, L.C.L.C. and Baccarin, R.Y.A., 2008. Nasal obstruction caused by fungal granuloma in a horse: Case report. Arch. Bras. Med. Vet. Zootec., 60: 315-321. https://doi.org/10.1590/S010209352008000200006 